\title{
Поєднання різних шляхів уведення хондропротекторних препаратів у лікуванні хворих на остеоартрит колінних суглобів I-II рентгенологічних стадій
}

\author{
Баранова I. В., Гуменюк А. Ф. \\ Вінницький національний медичний університет ім. М. І. Пирогова, м. Вінниця, Україна
}

Актуальність. Остеоартрит (ОА) відноситься до найбільш розповсюдженої патології суглобів, що охоплює близько $15 \%$ населення планети. Згідно з Європейськими рекомендаціями (ESCEO, 2014, 2017), застосування препаратів хондропротекторної дії $€$ перспективним напрямком лікування гонартриту. Дослідження останніх років неодноразово підтвердили симптомомодифікуючу та структурно-модифікуючу дію хондропротекторів, продемонстрували високу безпечність ї призначення при загостренні захворювання й на етапі реабілітації (Cochrane Database of Systematic Reviews, 2015; J. Martel-Pelletier et al., 2015; Raynauld J.P. et al., 2016).

Мета: порівняти ефективність різних шляхів уведення хондропротекторних препаратів у хворих на гонартрит I-II рентгенологічної стадії.

Матеріали та методи. Протягом 20152017 рр. під спостереженням перебувало 57 хворих (20 чоловіків та 37 жінок у віці $56 \pm 2,3$ року) з гонартритом I-II стадії за Н. Kellgren, J. S. Lawrence і тривалістю захворювання від 2 до 8 років. Усі хворі отримували парентеральне (в/м) введення хондроїтину сульфату 200 мг/2 мл № 25 через день. Пацієнти були рандомізовані на 2 групи. В основній групі додатково щоденно проводили процедури електрофорезу $35 \%$ хондроксид-гелем в імпульсному рухомому режимі, потужністю 0,6-0,8 Вт/см², № 15. Курси базисної парентеральної терапії хондроїтину сульфату та фізіотерапію повторювали двічі на рік протягом двох років. Методи обстеження хворих включали рентгенологічне та ультразвукове дослідження колінних суглобів, 100-бальну шкалу Лісхольма та опитувальник EQ-5D.

Отримані результати. Проведене лікування позитивно вплинуло на якість життя в обох групах згідно з опитувальником EQ-5D. Однак пацієнти основної групи достовірно вирізнялись покращенням функціональної здатності колінних суглобів за шкалою Лісхольма та відсутністю загострень захворювання. Через 2 роки спостереження у $87 \%$ пацієнтів основної групи та у $58 \%$ пацієнтів 2 групи не зафіксовано негативної УзДдинаміки по звуженню міжсуглобової щілини $(\mathrm{p}<0,05)$.

Перспективи подальших досліджень. Планується продовження зазначених курсів лікування у сформованих групах до 6 років з верифікацією подальшого терапевтичного ефекту із залученням інструментальних методів (УЗД та МРТ суглобів) і за допомогою опитувальників.

Висновки. Тривалі курси хондропротекторної терапії, що проводились парентерально в поєднанні 3 електрофорезом, мають переваги перед ізольованими системними курсами введення препаратів і здатні покращувати метаболічні процеси в суглобах, відновлювати ї функціональний стан та профілактувати загострення у пацієнтів 3 початковими стадіями ОА. 